\title{
NEUROPSYCHOLOGICAL CHARACTERISTICS OF YOUNG CHILDREN FROM HIGH-DENSITY ALCOHOLISM FAMILIES: A THREE-YEAR FOLLOW-UP
}

\author{
Authors: Montserrat Corral, Socorro Rodríguez Holguín, Fernando Cadaveira
}

This is the peer reviewed version of the following article: Corral, M., Rodríguez Holguín, S. \& Cadaveira, F. (2003). Neuropsychological characteristics of young children from high-density alcoholism families: A three-year follow-up. Journal of Studies on Alcohol, 64, 195-199. doi: 10.15288/jsa.2003.64.195.

This article may be used for non-commercial purposes in accordance with Alcohol Research Documentation and Rutgers University, Center of Alcohol Studies terms and conditions for use of self-archived versions. 
Neuropsychological characteristics of young children from high-density alcoholism families: A three-year follow-up

Authors: Montserrat Corral, Ph D*, Socorro Rodríguez Holguín, Ph D, and Fernando Cadaveira, Ph D.

Departamento de Psicoloxía Clínica e Psicobioloxía, Facultade de Psicoloxía, Universidade de Santiago de Compostela, Campus Sur. Santiago de Compostela, A Coruña 15782, Spain

Corresponding author: Montserrat Corral at the above address, or via email at mcorral@usc.es 


\begin{abstract}
Objective: We performed a follow-up study of a group of young children from high-density alcoholism families (HD children), who were first assessed about 3.5 years ago, with the aim of evaluating verbal span and visuospatial abilities (which differed significantly between HD and control $[\mathrm{C}]$ children at the first assessment), as well as other neuropsychological measures.
\end{abstract}

Method: In this second assessment, 22 boys and girls were evaluated. They were comparable in family income and parents' level of education. The $12 \mathrm{HD}$ children had an alcoholic father and at least two other alcoholic relatives, whereas the $10 \mathrm{C}$ children had no family history of alcoholism in either the first or second generation. A neuropsychological battery was set up with standardized tasks to measure attention, memory, visuospatial and executive functions.

Results: Analysis revealed significant Group x Assessment interactions in the digit span subtest where high-density children increased their performance until it reached that of the control children, and in the Wisconsin Card Sorting Test (WCST) where high-density children did not show the same improvement as the $\mathrm{C}$ children with maturation. A main effect was also observed for group factor in perseverative responses of the WCST. Conclusions: High-density children attain the same level of performance as control children for verbal span, but differences between groups increase over time for executive functioning as measured by the WCST. These results are considered in the context ofthe developmental delay hypothesis. The small sample size, however, means further studies will be necessary to confirm our findings.

Keywords: Alcoholism, Familial History, Neuropsychology, Children of alcoholics 


\section{Introduction}

During the last two decades, the young chil- dren of alcoholics have been described as having greater cardiovascular hyperreactivity, lower amplitudes and delayed latencies of the P3b component of event-related potentials (ERPs), a higher prevalence of behavioral prob- lems, and lower cognitive achievement than children with- out family histories of alcoholism. Many neuropsychological studies have demonstrated differences in performance for different tests of visuospatial, attentional and executive abilities (Berman and Noble, 1995; Harden and Pihl, 1995; Ozkaragoz and Noble, 1995; Ozkaragoz et al., 1997; Schandler et al., 1988, 1993; Tarter et al., 1989a,b, 1993; Whipple et al., 1988). The results were most consistent when the subjects carne from a background of high-density or multigenerational alcoholism (suggesting that genetic factors may be the cause of this reduced performance) and when the subjects were young children (suggesting that sorne differences may tend to disappear in adulthood). Sorne authors have linked these characteristics, particularly the psychophysiological characteristics, with other phenotypic and genotypic risk markers observed in the young children of alcoholics (Berman and Noble, 1997; Harden and Pihl, 1995). They have proposed models to explain the role of these variables in regard to vulnerability to alcoholism, suggesting that the characteristics of informationprocessing in these children may raise their stress levels, so that alcohol acquires a greater reinforcement value. Follow-up studies have revealed a relationship between specific psychophysiological markers and substance use in the children of alcoholics, supporting the predictive value of these markers (Berman et al., 1993; Hill et aL, 1995). However, as far as we know there have been no follow-up studies aimed at assessing long-term trends in neuropsychological variables in children from high-density alcoholism families.

In a previous study (Corral et al., 1999), we assessed 103 boys and girls aged between 7 and 15 and classified them into three groups according to their family history of alcoholism: High Density (HD), Low Density (LD) and Control group (C). Neuropsychological assessment revealed significant between-group differences in performance on at- tention and visuospatial tasks, with HD children showing lower performance than LD and C children in the Wechsler Intelligence Scale for Children-Revised (WISC-R) Block Design and Digit Span subtests. Specifically, HD children showed lower capacity in working memory and found it more difficult to organize complex visuospatial information. These results indicate that the children of alcoholics are not a homogeneous group; significant neuropsychological deficits are detected only in HD children. We did not detect any between-group differences in performance on the Wisconsin Card Sorting Test (WCST), which previous studies have found to be affected in the children of alco- holics. We suggested that this apparently conflicting result may have been due to the lack of children with psycho- pathological characteristics in our sample, although an altemative hypothesis is that the children were young at the time of assessment, and frontal development is not complete until adolescence. 
Here, we report a follow-up study of a representative subset of the HD and C children perfonned after an ínter- val of 3.5 years with the airo of assessing whether the observed neuropsychological deficits are maintained over development. Since LD children showed no differences from C children in our previous study, they were not included in the present follow-up.

\section{Method}

\section{Subjects}

We assessed 12 of the $32 \mathrm{HD}$ children and 10 of the $36 \mathrm{C}$ children who took part in the previous study. HD children had an alcoholic father and at least two other first or second-degree alcoholic relatives. $\mathrm{C}$ children had no family history of alcoholism in the first or second degree. The groups were comparable in age distribution $(\mathrm{F}=0.04,1120 \mathrm{df}, \mathrm{p}=.85)$, gender mix $\left(\chi^{2}=1.56,1 \mathrm{df}, \mathrm{p}=\right.$ .21 ), and hand-dominance as determined by the Edinburgh Inventory (Oldfield, 1971) $\left(\chi^{2}=2.229\right.$, $2 \mathrm{df}, \mathrm{p}=.33)$. Income $(\mathrm{F}=0.75,1120 \mathrm{df}, \mathrm{p}=.40)$, educational level of fathers $\left(\chi^{2}=3.16,2 \mathrm{df}, \mathrm{p}\right.$ $=.21)$ and educational level of mothers $\left(\chi^{2}=4.80,3 \mathrm{df}, \mathrm{p}=.19\right)$ did not differ significantly between the two groups. Table 1 shows the demographic characteristics of the groups. More details of the selection criteria may be found in Corral et al. (1999).

At interview, 6 of the 22 children (27.3\%) reported occasional consumption of alcohol andlor tobacco, and none reported illegal drug use. There were no significant between-group differences in alcohol/tobacco consumption $\left(\chi^{2}=1.43,1 \mathrm{df}, \mathrm{p}=.34\right)$. None of the parents reported any significant changes in psychopathological, medical or social problems since the first interview. None of the children showed major behavioral problems as defined by the Spanish version of the Child Behavior Checklist (CBCL; Achenbach, 1991). Almost all children obtained $\mathrm{T}$ scores within the normal range, with only two children one $\mathrm{C}$, one HD obtaining scores in the borderline clinical range for Aggressive Behavior and Attention Problems, respectively.

\section{Materials}

The same tasks that had revealed differences between the groups in the first assessment were used again, namely the Block Design and Digit Span subtests of the WISC-R (Wechsler, 1974); children over 16 were tested with the equivalent Wechsler Adult Intelligence Scale-R subtests (WAIS-R; Kaplan et al., 1991). Additional tests were used to assess memory and spatial processing in greater depth: the Rey Auditory-Verbal Leaming Test (RAVLT) (Rey, 1964) and Benton's Judgment of Line (JOL) Orientation (Benton et al., 1994). The former measures both short-term and longer term memory and provides an imrnediate verbal memory span, leaming curve, evidence about leaming strategies, and tendencies for retroactive (TrialVI) and proactive (List B) interference. Benton's JOL is a purely spatial test that examines the ability to estímate 
angular relationships between line segments. In previous studies, these tests detected differences between children with and children without family histories of alcoholism (Berrnan and Noble, 1995; Ozkaragoz and Noble, 1995; Whipple et al., 1988). A computerized version of the WCST (Neurosoft, Inc., Cardsort, Version 1.8, El Paso, TX, 1990) was also included to analyze any possible changes in the level of performance for each group of children in this task.

\section{Procedure}

Families of children were contacted by telephone about 3.5 years (mean 41.5 months) after the first assessment. The follow-up assessment included 12 of the $32 \mathrm{HD}$ children and 10 of the $36 \mathrm{e}$ children who had taken part in the previous assessment. The remaining families could not be included either because they had changed address and could not be located or because they refused to collaborate for various reasons. The absence of these earlier participants raises the possibility that the follow-up sample may not be a faithful representation of the initial sample, although the drop-out rate was similar for both groups, and the two follow-up groups were well-matched with respect to each other (see Subjects). To analyze this possibility, we compared the children with and without follow-up in each group. In the case of the $\mathrm{C}$ children, there were no significant differences in the proportion of boys and girls in mean age or in parents' educational level, although the families of children in the follow-up group had lower mean income. In the case of the HD children, there were no significant differences in any of these variables, except mean age, which was significantly lower in the follow-up group. These differences did not have any effect on the posterior intergroup comparisons, as is indicated in the Subjects section.

Fathers, mothers and children were independently interviewed at an initial session to gather information about the father's alcoholic status; alcohol, tobacco and other drug use by the child; and changes since first assessment in other aspects of interest (psychopathological, educational, physical and social). When it was not possible to obtain information from the father, the subject's mother answered the questions. Neuropsychological assessment took place at a second session, with the tests presented in the same order to all of the subjects. All parents signed a consent form before assessment and were paid for their participation

\section{Results}

\section{Group x Assessment interaction}

The results were first analyzed using a two-way ANOVA with repeated measures on one factor (Assessment). The Group x Assessment interaction was significant for the WISC-R Digits Forwards subtest $(\mathrm{F}=7.33,1120 \mathrm{df}, \mathrm{p}=.01)$ and the WCST Perseverative Responses $(\mathrm{F}=4.29$, $1 / 18 \mathrm{df}, \mathrm{p}=.05)$. These resu1ts reflect the fact that mean Digits Forwards score increased between 
first and second assessments in HD children, but remained roughly constant in $\mathrm{C}$ children; while mean Perseverative Responses score increased in HD children, and declined in $\mathrm{C}$ children. The other two measures considered did not show significant Group x Assessment interactions, (Digits Backwards, $\mathrm{F}=0.95,1 / 20 \mathrm{df}, \mathrm{p}=.34$; Block Design, $\mathrm{F}=0.007,1 / 19 \mathrm{df}, \mathrm{p}=.93$ ).

Group

The results for the second assessment only were next analyzed using a one-way ANOVA, with Group as the between-subject factor. Table 1 shows the mean scores obtained in each group. This analysis revealed a significant effect of Group on WCST Perseverative Responses, with the HD children making significantly more perseverative responses than the $C$ children $(F=4.30,1 / 19$ $\mathrm{df}, \mathrm{p}=.05)$. Two HD children had scores below the borderline range. Group had no significant effect on the other measurements considered (Digits Forwards, $F=0.62,1 / 20 \mathrm{df}, \mathrm{p}=.62$; Digits Backwards, $\mathrm{F}=0.07,1 / 20 \mathrm{df}, \mathrm{p}=.80$; Block Design, $\mathrm{F}=0.02,1119 \mathrm{df}, \mathrm{p}=.89$ ).

\section{Discussion}

The aim of this follow-up study of children with and without family histories of alcoholism was to determine whether the differences previously observed in attention and visuospatial tasks were maintained over development. We also assessed executive functioning (as measured by the WCST), which in the first assessment did not differ between HD and C children. In our first study of children aged 7-15 years, HD children $(n=32)$ were found to have significantly lower performance than e children $(n=36)$ on the Block Design and Digit Span subtests. In the present follow-up study performed 3.5 years later, the children now aged 11-17 years, the HD children (n = 12) appear to have "caught up," with neither of these variables differing significantly between the follow-up HD and the C children $(\mathrm{n}=10)$. On the other hand, executive functioning (WCST Perseverative Responses) measured in the second assessment was significantly worse in the HD children than in the $\mathrm{C}$ children. In executive functioning, then, differences were evident over development. Since executive functioning develops slowly and may not be complete until the frontal lobe has fully matured, this result is perhaps not surprising.

The improvement in verbal span indicated by the Digit Span subtest was supported by the results obtained with the RAVLT, which was applied only in the second assessment (i.e., no significant difference between HD and C children in Trial; see Table 1). Differences in Digit Span and RAVLT have been found on numerous occasions in stud- ies comparing the children of alcoholics with the children of nonalcoholics (Ozkaragoz and Noble, 1995; Ozkaragoz et al., 1997; Whipple et al., 1988), but not in studies comparing the adult children of alcoholics with the adult children of nonalcoholics (Bates and Pandina, 1992; Gillen and Hesselbrock, 1992; Sher et al., 1991). 
Gillen and Hesselbrock (1992) suggested this pattem may reflect a lag in development, meaning the differences become less evident or even disappear with age. Our results provide support to this hypothesis.

Visuospatial differences observed in the first assessment were likewise not present in the second assessment: specifically, there were no significant between-group differences in either of the visuospatial tasks used, JOL and Block Design. However, we must be cautious about this result, especially since two versions of the Block Design subtest were used (because the WISC$\mathrm{R}$ is limited to children younger than 16 years of age). We therefore compared the typical rather than the raw scores, which, together with the small size of the sample, may have contributed to the lack of statistically significant differences. We therefore believe future studies with larger samples are needed before firm conclusions can be reached about the developmental course of visuospatial performance in HD children.

In contrast, there were no significant between-group differences in the WCST initially, but the perseverative responses increased in HD children and declined in $\mathrm{C}$ children in the second assessment. In other words, the executive functioning of the HD children did not show the normal improvement with age. Other studies have also detected lower performance of children of alcoholics on executive tasks, and hypotheses of frontal dysfunction connected with vulnerability to alcoholism have been proposed (Peterson and Pihl, 1990; Tarter et al., 1990). In our previous study (Corral et al., 1999), we suggested that the lack of differences between groups was perhaps due to the absence of conduct problems or psychopathological disorders in HD children. A previous study reporting poorer performance by the children of alcoholics on the WCST showed a relationship with the conduct problems dimension of Conner's Parent Rating Scale (Harden and Pihl, 1995). In the present follow-up study, we not only used interviews to assess psychopathological disorders but also the Child Behavior Checklist to determine whether parents consider their children to have problems in this area. We did not detect any between-group difference in CBCL results, and in fact only two children, one from the $\mathrm{C}$ group and one from the HD group, obtained scores in the clinical borderline range. Neither did the scores for CBCL and WCST show any significant correlation. An altemative explanation for these results (i.e., poorer executive functioning in the HD children than in the $\mathrm{C}$ children at the second but not the first assessment) may be the children's young age at the first assessment. The frontal lobes, the brain regions that underlie the executive functions, are among the last to mature, so that the difficulties involving these functions may not become apparent until the child reaches adolescence. In fact, the adult level of performance for the WCST is not reached until the age of 10 (Riccio et al., 1994; Welsh et al., 1991). At the first assessment, the age range was 7-15 years, and $44.3 \%$ of the children were aged 10 or younger. Differences between groups were therefore perhaps diminished by a "floor effect" derived from the difficulty of the task. At the second assessment, all of the children were above the age threshold for adult performance on the WCST, and the differences 
may thus have been more easily detected, reflecting a lag in development or a definitively lower capacity among the HD children.

In conclusion, the present follow-up results suggest that HD children may have different pattems of cognitive development, or even delayed development, in comparison to children without a family history of alcoholism, thus highlighting the importance of age in vulnerability studies. Other authors have suggested there may be developmental delay in other characteristics. Hill and coworkers found that high density children showed slower rate of development of P300 amplitude and body sway than children without a family history of alcoholism (Hill et al., 1999, 2000), and they similarly interpreted the smaller volume of the right amygdala observed in high density children (Hill et al., 2001). The neuropsychological results of our study are consistent with these psychophysiological and neuroanatomic data, since although HD children were found to have sig- nificantly lower performance than $\mathrm{C}$ children on Block Design and Digit Span subtests at the first assessment (overall mean age 10.08 years, range 7-15), 3 years later (overall mean age 13.83, range 11-17) the HD children appear to have "caught up" with the $\mathrm{C}$ children. However, the small size of the sample dictates that these conclusions must be considered tentative until a much larger population has been evaluated.

\section{Acknowledgements}

This study was financed, in part, by the Ministerio de Educación y Cultura (Spain) with DGICYT grants (PB95-0856) awarded to Fernando Cadaveira.

\section{References}

ACHENBACH, T.M. Manual for the Child Behavior Checklist 4/18, Burlington, VT: Department of Psychiatry, University of Vermont, 1991.

BATES, M.E. \& PANDINA, R.J. FamiliaL alcoholism and premorbid cognitive deficit: A failure to replicate subtype differences. J. Stud. Alcohol 53: 320-327, 1992.

BENTON, A.L., SIVAN, A., HAMSHER, K., VARNEY, N. \& SPREEN, O. Contributions to Neuropsychological Assessment, 2nd Edition, New York: Oxford Univ. Press, 1994, pp. 53-64.

BERMAN, S.M. \& NOBLE, E.P. Reduced visuospatial performance in children with the D2 dopamine receptor Al allele. Behav. Genet. 25: 45-58, 1995.

BERMAN, S.M. \& NOBLE, E.P. The D2 dopamine receptor (DRD2) gene and family stress: Interactive effects on cognitive functions in children. Behav. Genet. 27: 33-43, 1997.

BERMAN, S.M., WHIPPLE, S.C., FITCH, R.J. \& NOBLE, E.P. P3 in young boys as a predictor of adolescent substance abuse. Alcohol 10: 69-76, 1993. 
CORRAL, M.M., RODRÍGUEZ HOLGUÍN, S.R. \& CADAVEIRA, F. Neuropsychological characteristics in children of alcoholics: Familial density. J. Stud. Alcohol 60: 509-513, 1999.

GILLEN, R. \& HESSELBROCK, V. Cognitive functioning, ASP, and family history of alcoholism in young men at risk for alcoholism. Alcsm Clin. Exp. Res. 16: 206-214, 1992.

HARDEN, P.W. \& PIHL, R.O. Cognitive function, cardiovascular reactivity and behavior in boys at high risk for alcoholism. J. Abnorm. Psychol. 104: 94-103, 1995.

HILL, S.Y., DE BELLIS, M.D., KESHAVAN, M.S., LOWERS, L., SHEN, S., HALL, J. \& PITTS, T. Right amygdala volume in adolescent and young adult offspring from families at high risk for developing alcoholism. Biol. Psychiat. 49: 894-905, 2001.

HILL, S.Y., MUKA, D., STEINHAUER, S. \& LOCKE, J. P300 amplitude decrements in children from families of alcoholic female probands. Biol. Psychiat. 38: 622-632, 1995.

HILL, S.Y., SHEN, S., LOCKE, J., LOWERS, L., STEINHAUER, S. \& KONICKY, C. Developmental changes in postural sway in children at high and Iow risk for developing alcohol-related disorders. Biol. Psychiat. 47: 501-511, 2000.

HILL, S.Y., SHEN, S., LOCKE, J., STEINHAUER, S.R., KONICKY, C., LOWERS, L. \& CONNOLLY, J. Developmental delay in P300 production in children at high risk for developing alcohol-related disorders. Biol. Psychiat. 46: 970-981, 1999.

KAPLAN, E., FEIN, D., MORRIS, R. \& DELIS, D. WAIS-R as a Neuropsychological Instrument, San Antonio, TX: Psychological Corp., 1991.

NEUROSOFT, INc. Cardsort, Version 1.8, El Paso, TX: Neurosoft, Inc., 1990.

OLDFIELD, R.C. The assessment and analysis of handedness: The Edinburgh Inventory. Neuropsychologia 9: 97-113, 1971.

OZKARAGOZ, T.Z. \& NOBLE, E.P. Neuropsychological differences between sons of active alcoholic and non-alcoholic fathers. Alcohol Alcsm 30: 115-123, 1995.

OZKARAGOZ, T., SATZ, P. \& NOBLE, E.P. Neuropsychological functioning in sons of active alcoholic, recovering alcoholic, and social drinking fathers. Alcohol 14: 31-37, 1997.

PETERSON, J.B. \& PIHL, R.O. Information processing, neuropsychological function and the inherited predisposition to alcoholism. Neuropsychol. Rev. 1: 343-369, 1990.

REY, A. L'examen Clinique en Psychologie, París, France: Presses Univ., 1964.

RICCIO, C.A., HALL, J., MARGAN, A., HYND, G.W. \& GONZÁLEZ, J. Executive function and the Wisconsin Card Sorting Test: Relationship with behavioral ratings and cognitive ability. Devel. Neuropsychol. 10: 215-229, 1994.

SCHANDLER, S.L., BRANNOCK, J.C., COHEN, M.J., ANTICK, J. \& CAINE, K. Visuospatial leaming in elementary school children with and without a family history of alcoholism. J. Stud. Alcohol 49: 538-545, 1988.

SCHANDLER, S.L., BRANNOCK, J.C., COHEN, M.J. \& MENDEZ, J. Spatial leaming deficits in adolescent children of alcoholics. Exp. Clin. Psychopharmacol. 1 (1-4): 207-214, 1993. 
SHER, K.J., WALITZER, K.S., WOOD, P.K. \& BRENT, E.E. Characteristics of children of alcoholics: Putative risk factors, substance use and abuse, and psychopathology. J. Abnorm. Psychol. 100: 427-448, 1991.

TARTER, R.E., JACOB, T. \& BREMER, D.A. Cognitive status of sons of alcoholic men. Alc. Clin. Exp. Res. 13: 232-235, 1989a.

TARTER, R.E., JACOB, T. \& BREMER, D.L. Specific cognitive impairment in sons of early onset alcoholics. Alc. Clin. Exp. Res. 13: 786-789, 1989 b.

TARTER, R.E., JACOB, T. \& LAIRD, S.B. Leaming and memory capacity in sons of alcoholic men. Amer. J. Addict. 2:219-224, 1993.

TARTER, R.E., LAIRD, S.B. \& MOSS, H.B. Neuropsychological and neurophysiological characteristics of children of alcoholics. In: WINOLE, M. \& SEARLES, J.S. (Eds.) Children of Alcoholics: Critical Perspectives, New York: Guildford Press, 1990, pp. 7398.

WECHSLER, D. Escala de Inteligencia de Wechsler para Niños- Revisada, Madrid, Spain: TEA, 1993. (Original work published, 1974).

WELSH, M.C., PENNINGTON, B.F. \& GROISSER, D.B. A normative-developmental study of executive function: A window on prefrontal function in children. Devel. Neuropsychol. 7: 131-149, 1991.

WHIPPLE, S.C., PARKER, E.S. \& NOBLE, E.P. An atypical neurocognitive profile in alcoholic fathers and their sons. J. Stud. Alcohol 49: 240-244, 1988. 
TABLE 1. Mean (SD) neuropsychological test scores obtained for each group at the first assessment (initial sample), at the first assessment (follow-up sample only) and at the second assessment

\begin{tabular}{|c|c|c|c|c|c|c|c|}
\hline & \multicolumn{3}{|c|}{$\begin{array}{l}\text { Assessment l } \\
\text { (initial sample) }\end{array}$} & \multicolumn{2}{|c|}{$\begin{array}{c}\text { Assessment } 1 \\
\text { (follow-up sample) }\end{array}$} & \multicolumn{2}{|c|}{ Assessment 2} \\
\hline & Control & Low-density & High-density & Control & High-density & Control & High-density \\
\hline \multicolumn{8}{|l|}{$\begin{array}{l}\text { Demographic } \\
\text { characteristics }\end{array}$} \\
\hline$N$ & 36 & 34 & 32 & 10 & 12 & 10 & 12 \\
\hline Age, years & $11.06(2.30)$ & $11.09(2.38)$ & $11.25(2.40)$ & $11.00(2.05)$ & $10.08(2.07)$ & $14.0(2.05)$ & $13.83(2.04)$ \\
\hline Range of age, years & $7-15$ & $7-15$ & $7-15$ & $8-14$ & $7-14$ & $11-17$ & $11-17$ \\
\hline Gender (male/female) & $19 / 17$ & $18 / 16$ & $14 / 18$ & $4 / 6$ & $8 / 4$ & $4 / 6$ & $8 / 4$ \\
\hline \multicolumn{8}{|l|}{$\begin{array}{l}\text { Neuropsychological tests } \\
\text { used in both assessments }\end{array}$} \\
\hline Digit Forwards ${ }^{a}$ & $5.97(1.23)$ & $5.79(1.15)$ & $5.27(0.98)$ & $6.10(1.52)$ & $5.08(0.79)$ & $5.90(0.74)$ & $6.17(0.83)$ \\
\hline Digit Backwards & $4.67(1.17)$ & $4.26(1.19)$ & $3.94(0.90)$ & $4.70(1.06)$ & $4.00(1.21)$ & $4.70(0.95)$ & $4.58(1.16)$ \\
\hline Block Design & $10.47(2.67)$ & $9.32(2.93)$ & $8.84(2.34)$ & $9.89(2.52)$ & $9.67(2.39)$ & $11.22(2.28)$ & $11.08(2.19)$ \\
\hline Perseverative Responses ${ }^{a, b}$ & $23.26(10.57)$ & $27.34(15.71)$ & $24.65(14.43)$ & $26.63(14.30)$ & $22.92(8.71)$ & $15.75(6.32)$ & $26.58(11.89)$ \\
\hline \multicolumn{8}{|l|}{$\begin{array}{l}\text { Neuropsychological tests used } \\
\text { only at the second assessment }\end{array}$} \\
\hline JOL (correct responses) & & & & & & $23.10(3.63)$ & $24.5(3.18)$ \\
\hline RAVLT-trial I & & & & & & $7.50(1.27)$ & $7.33(1.61)$ \\
\hline RAVLT-total & & & & & & $58.60(3.20)$ & $58.17(5.51)$ \\
\hline RAVLT-list B & & & & & & $6.50(1.43)$ & $6.50(1.24)$ \\
\hline RAVLT-trial VI & & & & & & $13.10(1.20)$ & $12.42(2.39)$ \\
\hline
\end{tabular}

${ }^{a}$ Group $\times$ Assessment $p \leq .05 ;{ }^{b}$ Group $p \leq .05$. 